\title{
Respiratory syncytial virus immunization in Sakarya, Turkey
}

\begin{abstract}
Background: Respiratory Syncytial Virus (RSV) is an important respiratory agent causing acute respiratory tract infections in every age group, especially below twoyear old infants. Congenital heart disease and prematurity are the leading risk factors. RSV immunization aims to prevent RSV among risk groups and is found to be efficient and safe. The aim of this descriptive study was to determine the frequency of admission to the hospital with the diagnosis of respiratory tract infections in children after RSV immunization and the opinions of the mothers about immunization, between October 2015 and March 2016
\end{abstract}

Methods: After ethical approval, the institution was informed about the methodology of the study. This study was conducted with mothers of babies younger than 24 months and who were immunized between October 2015 and March 2016. The data were collected through a questionnaire that was prepared by the researchers themselves. The data collected were analyzed in the computer environment by calculating percentages and averages

Results: All children were under their mothers' attendance $(n=58 ; 29.0 \pm 5.4$ years $50 \%$ primary/secondary school graduate, $79.3 \%$ not working, $70.7 \%$ nuclear family; $72.4 \%$ of middle-income level. Hospitalization duration at Newborn Intensive Care Unit was between 2 and 180 days (median 72 days). Ages of children were between 3 and 24 months, 40 of them were diagnosed with a chronic health situation; 23 of them had congenital heart anomaly/disease. Thirty-four children were on continuous medication. Hospitalization due to respiratory system infection in five months time before March was 9 days among 39 children who had respiratory system infection during the same period of time. According to most of the mothers $(n=31)$ immunization was protective against infections, and six mothers declared that the immunization was not safe.

Conclusion: The results showed that well planned prospective and local RSV studies are needed to make conclusions on routine RSV immunization need.

Keywords: respiratory syncytial virus, immunization, prematurity, newborn, bronchopulmonary dysplasia
Volume I Issue 4 - 2016

\section{Nursan Cinar,' Tuncay Müge Alvur, ${ }^{2}$ Oznur Tiryaki, ${ }^{3}$ Sinem Yalnizoglu Caka' \\ 'Department of Pediatric Nursing, Sakarya University, Turkey 2Department of Family Medicine, Kocaeli University, Turkey \\ ${ }^{3}$ Department of Nurse Education, Sakarya University, Turkey}

Correspondence: Nursan Cinar, Department of Pediatric Nursing, Sakarya University, Turkey, Tel +90264 295 6621, Fax +90264295 6602, Email ndede@sakarya.edu.tr

Received: November 22, 2016 | Published: December 30 2016
Abbreviations: RSV, respiratory syncytial virus; RTI, respiratory tract infections; CLD, chronic lung disease; CHD, congenital heart disease; BPD, bronchopulmonary dysplasia

\section{Background}

Respiratory tract infections are among the top four causes of morbidity and mortality in adults and children in Worldwide. ${ }^{1,2}$ Due to variety and difficulty of detecting viruses that cause respiratory infections, etiological diagnostics of viral infections has been limited with epidemiological purposes mostly. Widespread use of antiviral drugs in respiratory tract infections (RTI) made it necessary to detect the agent. ${ }^{1}$ Particularly recurrent RTI in children and nosocomial infections pose a public health risk. Bacteria, viruses and parasites causes RTI, approximately $20-60 \%$ of these infections are viral. ${ }^{2}$ The most important cause of lower respiratory tract infection in infancy and children younger than 2 years is respiratory syncytial virus (RSV) and highly contagious. ${ }^{2,3}$ For severe RSV disease; risk groups are children who have chronic lung disease (CLD), bronchopulmonary dysplasia (BPD), hemodynamically impaired congenital heart disease (CHD), neuromuscular and immune deficiency diseases, and prematurity. ${ }^{4,5}$
Seasonal features are important in RSV infection. Northern hemisphere epidemics associated with RSV occurs between October and June. ${ }^{6,7}$ RSV infections are the most important leading causes of severe respiratory diseases that require hospitalization. Infections are common in winter in temperate climates and, in the rainy season in tropical climates. Akçalı et al. ${ }^{1}$ carried their study in March because RSV was reported mostly between January-March. ${ }^{7}$

RSV cannot be cured but can be prevented. ${ }^{8}$ Due to the lack of a specific treatment against RSV, palliative treatment methods are often used. In patients with severe RTI, ancillary breathing methods can be used as a treatment option. ${ }^{9}$ Prophylaxis is used for the control of severe infections. For this purpose polyclonal RSV intravenous immunoglobulin (RSV-IVIG) and monoclonal antibodies (palivizumab) are used. Prophylactic antibody treatment is recommended only for high-risk patients due to the high cost. ${ }^{10,11}$

To protect against RSV infection education of the children and families about hand washing and the environmental cleaning, isolating infants and children with infection and, RSV prophylaxis (palivizumab) for children under risk are recommended. ${ }^{6,8}$ The aim of this study was to determine the frequency of admission to hospital with 
the diagnosis of respiratory tract infections after RSV immunization and the opinions of the mothers about immunization.

\section{Materials and methods}

This descriptive study was carried out at a State Hospital in Sakarya between October 2015 and March 2016. The population of the study consisted of 58 mothers after being informed by the researchers who agreed to participate, have babies younger than 24 months, meet the inclusion criteria (under 29 gestational weeks and, babies with cardiac problems that impair hemodynamic) and were immunized with Palivizumab (Synagis). Palivizumab (Synagis), a human monoclonal antibody against the RSV fusion protein, has been demonstrated to substantially reduce hospitalization for severe RSV in large clinical trials involving preterm infants..$^{12}$ Mothers who did not accept to join the study $(n=5)$ and whose children were still staying in the intensive care unit during data collection $(\mathrm{n}=1)$ were excluded from the study.

The mothers who met the inclusion criteria were informed about the objective of our study. They were informed that the data about their children would be kept private and they had the right to leave the study at any time. All the mothers who agreed to participate in this study also gave written permission after reading the informed consent form. The study was approved by the Ethical Board of Sakarya University and study started after receiving approval from related local authorities. The data were collected by face-to-face interviews with the mothers. The mothers were interviewed by using a questionnaire which was prepared by the researchers.

\section{Results}

All children were under their mothers' attendance. The mean age of the mothers $(n=58)$ was $29 . \pm 5.4$ years, and $50 \%$ of them were primary school graduates, $79.3 \%$ was not working, $70.7 \%$ was living in a nuclear family; $72.4 \%$ was of middle-income level Table 1.

Table I Descriptive characteristic of mothers

\begin{tabular}{lll}
\hline Characteristics & n & $\%$ \\
\hline Education level & & \\
Primary school & 20 & 34.5 \\
High School & 29 & 50 \\
University & 9 & 15.5 \\
Working status & & \\
Working & 12 & 20.7 \\
Not working & 46 & 79.3 \\
Family Type & & \\
Nuclear family & 41 & 70.7 \\
Extended family & 17 & 29.3 \\
Economical situation & & \\
Good & 41 & 70.7 \\
Middle & 17 & 29.3 \\
Bad & 41 & 70.7 \\
\hline
\end{tabular}

Mean rates of pregnancy was $1.90 \pm 0.83(\min : 1, \max : 3)$, number of living children was $1.71 \pm 0.70$ (min:1, max:4), and duration between the last pregnancies was $3.11 \pm 1.26$ years. Minimum number of doctor visits during the last pregnancy was 2 (max: 15); majority of births took place at a hospital $(\mathrm{n}=56)$.

Mean age of children was $12.22 \pm 5.37$ months, mean week of gestation was $31.10 \pm 6.05$ and birth weight average was 1683.71 $\pm 1116.70 \mathrm{gr}$ (min: 610gr, max: 4000gr). Birth age of 38 children was shorter than 37 weeks and 38 children's birth weight was below 2000gr. Average stay at Newborn Intensive Care Unit (NICU) was 66.36 \pm 39.33 days, Mean RSV Prophylaxis Dose was 4.21 \pm 1.28 times Table 2 .

Table 2 Descriptive characteristics of the children

\begin{tabular}{|c|c|c|c|}
\hline Variables $(n=58)$ & Min & $\operatorname{Max}$ & Mean士SD \\
\hline YAge (Month)aș & 3 & 24 & $12.22 \pm 5.37$ \\
\hline Gestation (Week) & 23 & 41 & $31.10 \pm 6.05$ \\
\hline Birth weight (gr) & 610 & 4000 & $|683.7| \pm 1|| 6.70$ \\
\hline Length of stay (NICU)* & 2 & 180 & $66.36 \pm 39.33$ \\
\hline RSV prophylaxis dose & 1 & 5 & $4.21 \pm 1.28$ \\
\hline
\end{tabular}

*Neonatal Intensive Care Unit.

Six of the mothers had a history of premature baby; the most frequently $(n=43)$ mentioned difference between term and premature baby was "growth and development". Hospitalization duration at NICU was between 2 and 180 days (median 72 days). Ages of children were between 3 and 24 months and 40 of them had a diagnosed chronic health situation; 23 of them with congenital heart anomaly/disease Table 3. Thirty four children were on continuous medication. Prevention against infections was the most frequently $(n=31)$ mentioned benefit of the vaccine and six mothers declared that the vaccine was not safe. Hospitalization due to respiratory system infection in five months time before March was 9 days among 39 children who had respiratory system infection during the same period of time.

Table 3 Indications and number of children*

\begin{tabular}{ll}
\hline Indication & $\begin{array}{l}\text { Number of } \\
\text { children }\end{array}$ \\
\hline $\begin{array}{l}\text { Younger than } 2 \text { years, under medical care for chronic } \\
\text { respiratory disease for } 6 \text { months }\end{array}$ & 31 \\
$\begin{array}{l}\text { Younger than } 2 \text { years, cyanotic or non-cyanotic heart } \\
\text { disease }\end{array}$ & 23 \\
Younger than 12 months, Birth age<29 weeks & 20 \\
$\begin{array}{l}\text { Children younger than } 12 \text { months and who have } \\
\text { congenital anomaly or neurologic disease that effect } \\
\text { respiratory system }\end{array}$ & 10 \\
\hline
\end{tabular}

*Due to more than one indication the total is greater than the study group $(n=58)$.

\section{Discussion}

Although the incidence and intensity of RSV infections vary at each year, it is one of the main factors that cause infection..$^{13}$ It is estimated that 132,000-172,000 children under five years of age require medical care in the US each year. ${ }^{14}$ Furthermore, in many countries, RSV is comparable to influenza regarding mortality rates and health and 
economic burdens in children. ${ }^{15}$ In Turkey, it is estimated that there are 30,000-45,000 hospital admissions per year due to RSV among children under five years. ${ }^{7}$ In a study in Turkey, 376 children under two years of age were hospitalized every year in Bursa due to RSVRTI and this figure is estimated as 18,800 for Turkey (12). Hafizoglu et al. ${ }^{9}$ presented 50 children between 2 months and 1 year age who admitted to the emergency with lower RTI. RSV antigen was positive in $23 .{ }^{9}$ Frobert et al. ${ }^{16}$ found RSV as the most frequently detected virus in intensive care unit. ${ }^{16}$ In another study RSV was the most frequently detected agent $61.2 \%(41 / 67)$ among 160 children. ${ }^{1}$ In our study, 39 mothers reported that their children's diagnosis were related to respiratory system.

RSV infection is usually resolves spontaneously in healthy children. However, premature infants require hospitalization and intensive care. ${ }^{17,18}$ Karaman et al. ${ }^{19}$ reported asthma attacks and wheezing in children who had RSV infection history. ${ }^{19}$ There is evidence that palivizumab prophylaxis is effective in reducing the frequency of hospitalizations due to RSV infection, i.e. in reducing the incidence of serious lower respiratory tract RSV disease in children with chronic lung disease, congenital heart disease or those born preterm..$^{20}$ Blanken et al reported a relative reduction of $61 \%$ in the total number of wheezing days during the first year of life among 429 premature children with palivizumab. ${ }^{21}$ Furthermore, limited studies reported that RSV immunization reduce the rate of hospitalizations due to RSV infection. ${ }^{22-25}$ In our study, hospitalization with a diagnosis of respiratory infection among immunized children was 23\% (9 out of 39 patients) which implies a desired immunity.

The mothers' knowledge and "feeling" were mostly (31/39) related to protective effects of RSV vaccine. In the current medical literature there aren't any papers on mothers' knowledge on RSV vaccine. In this respect, our study is the first study on this subject in our country and the results seem to support the necessity of further investigations.

\section{Study limitations}

We were not able to track the families' education on RSV immunization and their knowledge about protection from infections.

\section{Acknowledgements}

The authors would like to appreciate the mothers who kindly participated in this research.

\section{Conflict of interest}

The authors disclose not receipt of financial funding or support for the research.

\section{References}

1. Akçalı S, Yılmaz N, Güler Ö, et al. Frequency of respiratory viruses in children with lower respiratory tract infection. Türk Ped Arş. 2013;48(3):215-220

2. Çiçek C, Arslan A, Karakuș HS, et al. Akut solunum yolu enfeksiyonu olan hastalarda solunum viruslarinin prevalansi ve mevsimsel dağılımı. Mikrobiyol Bul. 2015;49(2):188-200.

3. Yalaz M, Kültürsay N. Respiratuar sinsisyal virus enfeksiyonu ve riskli bebeklerde palivizumab profilaksisi. Çocuk Sağlığl ve Hastalıklar Dergisi. 2014;57(3):200-213.

4. Butt ML, Symington A, Janes M, et al. The impact of prophylaxis on pediatric intensive care unit admissions for RSV infection: a retrospective, single-centre study. Eur J Pediatr. 2011;170(7):907-913.
5. Whelan B, Murray A, Moore E, et al. Review of the home care programmes for respiratory syncytial virus (RSV) prophylaxis in Ireland and The Netherlands. Drugs Ther Perspect. 2016;32:119-130.

6. Bollani L, Baraldi E, Chirico G, et al. Revised recommendations concerning palivizumab prophylaxis for respiratory syncytial virus (RSV). Ital J Pediatr. 2015;41:97-104.

7. Hacımustafaoğlu M. RSV İnfeksiyonları. ANKEM Derg. 2014;28(Supp 2):240-247.

8. Beek DV, Paes B, Bont L. Increased risk of RSV infection in children with down's syndrome: clinical implementation of prophylaxis in the european union. Clinical and Developmental Immunology. 2013 p. 1-6.

9. Hafızo $\breve{g l u ~ T, ~ S ̧ i l f e l e r ~} \dot{\boldsymbol{I}}$, Tanıdır $\dot{\boldsymbol{I} C}$, et al. Alt Solunum yolu enfeksiyonu olan bebeklerde respiratuvar sinsitiyal virüs siklĭgi ve klinik özellikleri. Mustafa Kemal Üniv Tip Derg. 2012;3(12):19-27.

10. Simoes EA, Groothuis JR, Estrany CX, et al. Palivizumab prophylaxis, respiratory syncytial virus, and subsequent recurrent wheezing. J Pediatr. 2007;151(1):34-42.

11. Mansbach J, Kunz S, Acholonu U, et al. Evaluation of compliance with palivizumab recommendations in a multicenter study of young children presenting to the emergency department with bronchiolitis. Pediatr Emerg Care. 2007;23(6):362-367.

12. Pedraz C, Estrany CX, Aloy FJ, et al. Effect of palivizumab prophylaxis in decreasing respiratory syncytial virus hospitalizations in premature infants. Pediatr Infect Dis J. 2003;22(9):823-827.

13. Hacimustafaoglu M, Celebi S, Elmas Bozdemir Ş, et al. RSV Frequency in children below two years hospitalized for lower respiratory tract infections. Turk J Pediatr. 2013;55(2):130-139.

14. Stockman LJ, Curns AT, Anderson LJ, et al. Respiratory syncytial virusassociated hospitalizations among infants and young children in the United States. Pediatr Infect Dis J. 2012;31(1):5-9.

15. Moore HC, Jacoby P, Hogan AB, et al. Modeling the seasonal epidemics of respiratory syncytial virus in young children. PloS one. 2014;9(6):1-8.

16. Frobert E, Escuret V, Javouhey E, et al. Respiratory viruses in children admitted to hospital intensive care units: evaluating the CLART Pneumovir DNA array. J Med Virol. 2011;83(1):150-155.

17. Smyth RL, Openshaw PJ. Bronchiolitis. Lancet. 2006;368(9532):312322.

18. Rueda JD, Rosselli D, Ruiz JG. Cost-effectiveness of respiratory syncytial virus infection (RSV) prophylaxis with palivizumab in preterm infants in Colombia. Investigación Económica Y Social. 2013;XLIII(2):137-151.

19. Karaman Ö, Güneş TB, Erbayraktar Z, et al. Recurrence of wheezing episodes in children with respiratory syncytial virus and non-respiratory syncytial virus bronchiolitis. J Med Sci. 2011;31(6):1507-1513.

20. Andabaka T, Nickerson JW, Reyes RMX, et al. Monoclonal antibody for reducing the risk of respiratory syncytial virus infection in children. Cochrane Database of Systematic Reviews. 2013;8(6):2243-2376.

21. Blanken MO, Rovers MM, Molenaar JM, et al. Respiratory syncytial virus and recurrent wheeze in healthy preterm infants. New England Journal of Medicine. 2013;368(19):1791-1799.

22. Piedra PA, JewellAM, Cron SG, et al. Correlates of immunity to respiratory Syncytial virus (RSV) associated-hospitalization: establishment of minimum protective threshold levels of serum neutralizing antibodies. Vaccine. 2003;21(24):3479-82.

23. Eick A, Karron R, Shaw J, et al. The role of neutralizing antibodies in protection of American Indian infants against respiratory syncytial virus disease. The Pediatric infectious disease journal. 2008;27(3):207-212. 
24. Broadbent L, Groves H, Shields MD, et al. Respiratory syncytial virus, an ongoing medical dilemma: an expert commentary on respiratory syncytial virus prophylactic and therapeutic pharmaceuticals currently in clinical trials. Influenza and other respiratory viruses. 2005;9(4):169178
25. Singleton RJ, Bruden D, Bulkow LR, et al. Decline in respiratory syncytial virus hospitalizations in a region with high hospitalizastion rates and prolonged season. Pediatr infect dis j. 2006;25(12):1116-1122. 